\title{
Effect of Foliar Applied for Humic and Fulvic Acids as a Partial Substitute for Mineral Nitrogen on some Characteristics of Two Hybrids of Grain Sorghum
}

\author{
Aml A. Tag El-Din, Heba M. Hafez and O.A.Y., Abd Elraheem \\ Sorghum Research Department., Field Crops Research Institute, ARC, Egypt
}

Received on: 19-8-2021

Accepted on: 14-10-2021

\begin{abstract}
This study was carried out during 2019 and 2020 seas ons at ArabEl-Awamer Station, Assiut, Egypt to examine the effect of foliar application of humic and fulvic acids with $25 \mathrm{ml} / \mathrm{L}$ to improve soil properties with mineral nitrogen at $100 \%$ and $75 \%$ of the recommended dose on grain yield and its components. Humic and fulvic acids applied were individually or in combination of themat a ratio of 1:1 with $\mathrm{N} 75 \%$. The obtained results showed that significant or highly significant effect between the genotypes for plant height and panicle length at two seasons. While the genotypes had a significant effect on grain ard / fed in the first seas on. The genotype hybrid Shandaweel-1 exhibited better results than the genotype hybrid -306 in most of the studied traits. Results of the present study als o show that all the studied traits were significantly affected by the fertilization treatments. Among the fertilization treatments applied the treatment $(\mathrm{N} 75 \%+\mathrm{H}+\mathrm{F})$ recorded the highest value s for most of the studied parameters. The interaction between genotypes and treatments had a significant effect on the days to $50 \%$ flowering in the second season, while on 1000-kernel weight the interaction between genotypes and treatments had a significant effect in the first season. Fromthe above results it could be recommended economically using of $(\mathrm{N} 75 \%+\mathrm{H}+\mathrm{F})$, thus we could save $25 \%$ of the recommended dose of $\mathrm{N}$ and improve soil properties.
\end{abstract}

KEYWORDS: Grain sorghum, Genotypes, Humic acid, Fulvic acid, Mineral nitrogen.

\section{INTRODUCTION}

Grain sorghum (sorghum bicolor L. Monech) is the third most important summer cereal crops after rice and maize in Egypt. Approximately 350 thousand feddan cultivated area in Middle and Upper Egypt. Third of this area presented in Fyoum governorate which most of its soils is low fertility (Economic Affairs Sector 2020). Grain sorghum is characterized by its ability to tolerate drought, salinity, and heat. The grain sorghum cultivated in the end of canals, the soils which suffer from salinity and drought as well as new Reclaimed. The humic acid and fulvic acid were enhancing the soil properties. And increase soil exchange capacity for ions and cations this increases the plants ability to benefit the most of soil elements. Foliar application of humic acid helps photosynthesis and promotes enzymatic activities, beside inhibit some other enzymes, However, it was found that humic acid helps plants to thrive salinity, drought, and heat, and activates several plant reactions (Shalash et al. 2011). Fagbenro and Agboola (1993) found that foliar nutrition with humic acid increased leaf biomass. Delfine et al. (2005) reported that spraying humic acid on wheat plants increase biological yield, meanwhile, Kauser and Azam (2006) found similar results.
Working on wheat, Ulukan (2008) found humic acid increased number of spikes in unit of area, number of grains/spike and grain weight. Sabzevari et al. (2010) discovered a similar result in wheat biological yield. Bulent et al. (2009) investigated the effects of humic acid on the "Triticum durum Salihli" species. The findings demonstrated that humic acid improves phosphorus, potassium, magnesium, sodium, copper, and zinc absorption in plants. Dulaimy and ElFahdawi (2020) found significant variations among the humic acid concentrations studied. So, the objective of this study was to evaluate the response of two grain sorghum genotypes to treatment foliar application by humic and fulvic acids as a partial substitute for mineral nitrogen.

\section{MATERIAL AND METHODS}

A field experiment was carried out at Arab ElAw amer Station, Assiut, Egypt during 2019 and 2020 seasons to examine the effect foliar application of humic $(\mathrm{H})$ and fulvic $(\mathrm{F})$ acids as partial alternatives to mineral nitrogen $(\mathrm{N})$ for two hybrids of grain sorghum on grain yield components for two hybrids of grain sorghum. Soil of the experimental site was analyzed in both 2018 and 2019 seasons according to (Chapman 
and Pratt, 1978) and results are shown in (Table 1). The experiment was set up using a randomized complete blocks design (RCBD) with three replications and a strip-plot arrangement. Used in this study two genotypes of grain sorghum (i.e., hybrid Shandaweel-1 and hybrid-306). Nitrogen fertilizer was applied in the form of ammonium nitrate $(33.5 \% \mathrm{~N})$ at $100 \%$ and $75 \%$ of the recommended dose. Humic and fulvic acids applied were at rate of $25 \mathrm{ml} / \mathrm{L}$ individually or in combination of them at a ratio of 1:1 with $\mathrm{N} 75 \%$. The genotypes (hybrid Shandaweel-1 and hybrid-306) were assigned vertically while, fertilization treatments (N 100\%, N 75\% + H, N 75\% + F and N 75\% + H + F) were allocated horizontally. Foliar applic ation of humic and fulvic acids at rate of 5 liters / 200 liters water per fed. Two spraying times were done at 30 and 45 days after planting

Table 1. Some physical and chemical properties of experimental site.

Chemical properties

\begin{tabular}{|c|c|c|c|c|c|c|c|c|c|}
\hline \multirow{2}{*}{$\begin{array}{l}\mathrm{PH} \\
(1: 1)\end{array}$} & \multirow{2}{*}{$\begin{array}{l}\text { EC } \\
\text { ds/m } \\
(1: 1)\end{array}$} & \multicolumn{4}{|c|}{ Soluble cations (meq / L) } & \multicolumn{4}{|c|}{ Soluble anions (meq / L) } \\
\hline & & $\mathrm{Ca}++$ & $\mathrm{Mg}++$ & $\mathrm{Na}+$ & $\mathrm{K}+$ & $\begin{array}{l}\mathrm{CO} 3- \\
+\mathrm{HCO} 3-\end{array}$ & $\mathrm{CL}^{-}$ & $\begin{array}{l}\text { Available phosphorus } \\
\text { (ppm) }\end{array}$ & $\begin{array}{l}\text { Total nitrogen } \\
(\%)\end{array}$ \\
\hline 8.37 & 0.33 & 1.43 & 1.16 & 0.19 & 0.75 & 1.68 & 1.47 & 8.31 & 0.009 \\
\hline
\end{tabular}

\section{Physical properties}

\begin{tabular}{|c|c|c|c|c|c|c|c|c|c|}
\hline \multicolumn{3}{|c|}{$\begin{array}{l}\text { Particle size distribution } \\
(\%)\end{array}$} & \multirow{2}{*}{$\begin{array}{l}\text { Texture } \\
\text { class }\end{array}$} & \multicolumn{2}{|c|}{$\begin{array}{l}\text { Moisture } \\
\text { (Volumetric \%) }\end{array}$} & content & \multirow{3}{*}{$\begin{array}{l}\begin{array}{l}\text { O.M } \\
(\%)\end{array} \\
0.19\end{array}$} & \multirow{3}{*}{$\begin{array}{l}\mathrm{CaCO3} \\
(\%)\end{array}$} & \multirow{3}{*}{$\begin{array}{l}\text { Bulk density } \\
1.63\end{array}$} \\
\hline Sand & Silt & Clay & & S.P & F.C & W.P. & & & \\
\hline 89.9 & 7.1 & 3.0 & Sandy & 23.3 & 10.9 & 4.5 & & & \\
\hline
\end{tabular}

\subsection{Parameters were recorded}

Plant height $(\mathrm{cm})$, days to $50 \%$ flowering, panicle length $(\mathrm{cm})$, panicle width $(\mathrm{cm}), 1000$-kernel weight (g), and grain yield (ard /fed). The SAS Statistical Software Package v.9.2 was used to evaluate all of the collected data using analysis of variance (ANOVA) procedures (SAS, 2008). Differences between means were compared by the revised least signific ant difference (RLSD) at 5\% level of significant (Gomez and Gomez, 1984).

\section{RESULTS AND DISCUSSION}

Data presented in Table (2) show that the hybrid-306 higher than significantly hybrid Shandaweel-1 the highly significant effect on plant height trait in the two growing seasons.

Table 2. Effect of humic (H)and fulvic(F) acids as partial alternatives to mineral nitrogen (N) and their interaction of two genotypes of grain sorghum on plant height $(\mathrm{cm})$.

\begin{tabular}{|c|c|c|c|c|c|c|}
\hline \multirow[b]{3}{*}{ Fertilization treatments } & \multicolumn{3}{|l|}{2019} & \multicolumn{3}{|l|}{2020} \\
\hline & \multicolumn{2}{|l|}{ Genotypes } & \multirow[b]{2}{*}{ Mean } & \multicolumn{2}{|l|}{ Genotypes } & \multirow[b]{2}{*}{ Mean } \\
\hline & $\begin{array}{l}\text { Hybrid } \\
\text { Shandaweel-1 }\end{array}$ & $\begin{array}{l}\text { Hybrid - } \\
306\end{array}$ & & $\begin{array}{l}\text { Hybrid } \\
\text { Shandaweel-1 }\end{array}$ & $\begin{array}{l}\text { Hybrid- } \\
306\end{array}$ & \\
\hline N $100 \%$ & 152.27 & 161.67 & 156.97 & 152.83 & 160.5 & 156.67 \\
\hline N 75\% + H $(25 \mathrm{ml} / \mathrm{L})$ & 156.1 & 159.53 & 157.82 & 157.57 & 158.77 & 158.17 \\
\hline $\mathrm{N} 75 \%+\mathrm{F}(25 \mathrm{ml} / \mathrm{L})$ & 157.77 & 162 & 159.88 & 157.83 & 161.9 & 159.87 \\
\hline $\mathrm{N} 75 \%+\mathrm{H}+\mathrm{F}(25 \mathrm{ml} / \mathrm{L})$ & 161 & 164.13 & 162.57 & 162.47 & 163.47 & 162.97 \\
\hline \multirow[t]{2}{*}{ Mean } & 156.78 & 161.83 & & 157.68 & 161.16 & \\
\hline & F test & LSD 0.05 & & F test & LSD 0.05 & \\
\hline Fertilization treatments & $*$ & 3.9 & & $*$ & 3.92 & \\
\hline Genotypes & $* *$ & 2.75 & & * & 2.77 & \\
\hline Interaction & - & - & & - & - & \\
\hline
\end{tabular}

*and ** mean significant 5 and $1 \%$ at level of probability, respectively. 
The second factor, the highest mean values of plant height were by adding $\mathrm{N} 75 \%+\mathrm{H}(25 \mathrm{ml} / \mathrm{L})+\mathrm{F}$ $(25 \mathrm{ml} / \mathrm{L})(162.57$ and $162.97 \mathrm{~cm}$ in the two respective seasons), compared to (156.97and $156.67 \mathrm{~cm}$ in control plants), were showed in Table (2) the interaction between hybrids and humic with fulvic acids was not significant in plant height in two seasons. This is may be due to the genetic makeup with environmental conditions which was suitable for hybrid-306 grain sorghum genotype than hybrid Shandaweel-1. Similar trend was observed by Hasssan et al. (2014) and Assefa et al. (2020) and these findings are in a good line with those obtained by Ulukan (2008) and Jamal \& Baghi (2014).
Data in Table (3) reported that the deference between two hybrids in days to $50 \%$ flowering was not significant in two seasons. The second factor, the plants treated by adding $\mathrm{N} 75 \%+\mathrm{H}(25 \mathrm{ml} / \mathrm{L})+\mathrm{F}(25$ $\mathrm{ml} / \mathrm{L}$ ) initiated flowering after (83.67 day) in the two seasons, as against (85.83 and 85.50 day in the two respective seasons in control plants), no significant for the interaction between treatments concentration and grain sorghum hybrids in the first season but signific ant in the second season. The obtained results are in agreement with those of Hasssan et al. (2014) and Assefa et al. (2020).

Table 3. Effect of humic $(\mathrm{H})$ and fulvic $(\mathrm{F})$ acids as partial alternatives to mineral nitrogen $(\mathrm{N})$ and their interaction of two genotypes of grain sorghum on days to $50 \%$ flowering

\begin{tabular}{|c|c|c|c|c|c|c|}
\hline Seasons & 2019 & & & 2020 & & \\
\hline \multirow[b]{2}{*}{ Fertilization treatments } & \multicolumn{2}{|l|}{ Genotypes } & \multirow[b]{2}{*}{ Mean } & \multicolumn{2}{|l|}{ Genotypes } & \multirow[b]{2}{*}{ Mean } \\
\hline & $\begin{array}{l}\text { Hybrid } \\
\text { Shandaweel-1 }\end{array}$ & $\begin{array}{l}\text { Hybrid } \\
-306\end{array}$ & & $\begin{array}{l}\text { Hybrid } \\
\text { Shandaweel-1 }\end{array}$ & $\begin{array}{l}\text { Hybrid - } \\
306\end{array}$ & \\
\hline N 100\% & 86 & 85.67 & 85.83 & 86.67 & 84.33 & 85.5 \\
\hline N 75\% + H $(25 \mathrm{ml} / \mathrm{L})$ & 86 & 85.33 & 85.67 & 84.67 & 85.67 & 85.17 \\
\hline N $75 \%+F(25 \mathrm{ml} / \mathrm{L})$ & 84.67 & 84.67 & 84.67 & 83.67 & 84 & 83.83 \\
\hline $\mathrm{N} 75 \%+\mathrm{H}+\mathrm{F}(25 \mathrm{ml} / \mathrm{L})$ & 83.67 & 83.67 & 83.67 & 83 & 84.33 & 83.67 \\
\hline \multirow[t]{2}{*}{ Mean } & 85.08 & 84.83 & & 84.5 & 84.58 & \\
\hline & F test & LSD 0.05 & & F test & LSD 0.05 & \\
\hline Fertilization treatments & $*$ & 1.51 & & $*$ & 1.28 & \\
\hline Genotypes & - & - & & - & - & \\
\hline Interaction & - & - & & $*$ & 1.81 & \\
\hline
\end{tabular}

*and ** mean significant 5 and $1 \%$ at level of probability, respectively.

Data in Table (4) showed that the deference between the two hybrids was high significant for panicle length during the two seasons of study. Panicle length for hybrids-306 increased greater than panicle length for hybrid Shandaweel-1. This is may be due to the genetic makeup with environmental conditions which was suitable for hybrids-306 than hybrid Shandaweel-1. Similar trend was observed by Hasssan et al. (2014) and Assefa et al. (2020). The second factor (humic and fulvic acids with nitrogen) treatments in the same tables showed that the highest mean values of panicle length $(29.12$ and $29.93 \mathrm{~cm})$ in the two seasons were detected from grain sorghum plants which were treatment by $\mathrm{N} 75 \%+\mathrm{H}+\mathrm{F}$, compared to (27.45 and $26.95 \mathrm{~cm}$ in control plants) in the two respective seasons. The interaction between hybrids and humic and fulvic acids with nitrogen was not signific ant in two seasons.

The recorded data in Table (5) denote that the tested grain sorghum genotypes had no significant influence on panicle width in the two seasons. The highest mean values of panicle width (6.83 and 6.85 $\mathrm{cm}$ in the two respective seasons were detected from grain sorghum plants which were treatment by $\mathrm{N} 75 \%$ $+\mathrm{H}+\mathrm{F}$, compared to $(5.82$ and $5.72 \mathrm{~cm})$ in control plants. These results are in harmony with those obtained by Hasssan et al. (2014) and Assefa et al. (2020). 
Aml A. Tag El-Din et al., 2021

Table 4. Effect of humic (H) and fulvic (F) acids as partial alternatives to mineral nitrogen (N) and their interaction of two genotypes of grain sorghum on panicle length

\begin{tabular}{|c|c|c|c|c|c|c|}
\hline Seasons & 2019 & & & 2020 & & \\
\hline \multirow[b]{2}{*}{ Fertilization treatments } & \multicolumn{2}{|l|}{ Genotypes } & \multirow[b]{2}{*}{ Mean } & \multicolumn{2}{|l|}{ Genotypes } & \multirow[b]{2}{*}{ Mean } \\
\hline & $\begin{array}{l}\text { Hybrid } \\
\text { Shandaweel-1 }\end{array}$ & $\begin{array}{l}\text { Hybrid } \\
306\end{array}$ & & $\begin{array}{l}\text { Hybrid } \\
\text { Shandaweel-1 }\end{array}$ & $\begin{array}{l}\text { Hybrid - } \\
306\end{array}$ & \\
\hline N 100\% & 28.17 & 26.73 & 27.45 & 27.87 & 26.03 & 26.95 \\
\hline $\mathrm{N} 75 \%+\mathrm{H}(25 \mathrm{ml} / \mathrm{L})$ & 28.43 & 26.30 & 27.37 & 28.17 & 26.80 & 27.48 \\
\hline $\mathrm{N} 75 \%+\mathrm{F}(25 \mathrm{ml} / \mathrm{L})$ & 29.30 & 27.77 & 28.53 & 30.23 & 26.83 & 28.53 \\
\hline N 75\% + H +F & 29.33 & 28.90 & 29.12 & 31.47 & 28.40 & 29.93 \\
\hline \multirow[t]{2}{*}{ Mean } & 28.81 & 27.43 & & 29.43 & 27.02 & \\
\hline & F test & LSD 0.05 & & F test & LSD 0.05 & \\
\hline Fertilization treatments & $* *$ & 0.82 & & $*$ & 1.87 & \\
\hline Genotypes & $* *$ & 0.58 & & $* *$ & 1.33 & \\
\hline Interaction & - & - & & - & - & \\
\hline
\end{tabular}

Table 5. Effect of humic (H) and fulvic (F) acids as partial alternatives to mineral nitrogen (N) and their interaction of two genotypes of grain sorghum on panicle width.

\begin{tabular}{|c|c|c|c|c|c|c|}
\hline Seasons & 2019 & & & 2020 & & \\
\hline \multirow{2}{*}{ Fertilization treatments } & \multicolumn{2}{|l|}{ Genotypes } & \multirow[b]{2}{*}{ Mean } & \multicolumn{2}{|l|}{ Genotypes } & \multirow[b]{2}{*}{ Mean } \\
\hline & $\begin{array}{l}\text { Hybrid } \\
\text { Shandaweel-1 }\end{array}$ & $\begin{array}{l}\text { Hybrid - } \\
306\end{array}$ & & $\begin{array}{l}\text { Hybrid } \\
\text { Shandaweel-1 }\end{array}$ & Hybrid -306 & \\
\hline N100\% & 5.87 & 5.77 & 5.82 & 5.67 & 5.77 & 5.72 \\
\hline $\mathrm{N} 75 \%+\mathrm{H}(25 \mathrm{ml} / \mathrm{L})$ & 6.27 & 6.10 & 6.18 & 6.10 & 6.27 & 6.18 \\
\hline $\mathrm{N} 75 \%+\mathrm{F}(25 \mathrm{ml} / \mathrm{L})$ & 6.53 & 6.27 & 6.40 & 6.53 & 6.60 & 6.57 \\
\hline $\mathrm{N} 75 \%+\mathrm{H}+\mathrm{F}(25 \mathrm{ml} / \mathrm{L})$ & 6.77 & 6.90 & 6.83 & 6.93 & 6.77 & 6.85 \\
\hline \multirow[t]{2}{*}{ Mean } & 6.36 & 6.26 & & 6.31 & 6.35 & \\
\hline & F test & LSD 0.05 & & F test & LSD 0.05 & \\
\hline Fertilization treatments & $* *$ & 0.48 & & $* *$ & 0.31 & \\
\hline Genotypes & - & - & & - & - & \\
\hline Interaction & - & - & & - & - & \\
\hline
\end{tabular}

*and $* *$ mean significant 5 and $1 \%$ at level of probability, respectively.

Data presented in Table (6) show that the genotypes did not significantly effect on trait 1000kernel weight during the two seasons of study. The interaction between grain sorghum hybrids and fertilization treatments had a significant effect on 1000-kernel weight in the first season. The highest mean values of 1000 -kernel weight ( 27.40 and $27.67 \mathrm{~g}$ ) in the two respective seasons were detected from grain sorghum plants which were treatment by $\mathrm{N} 75 \%+\mathrm{H}$ $+\mathrm{F}(25 \mathrm{ml} / \mathrm{L})$, compared to 26.08 and $25.80 \mathrm{~g}$ in control plants) in the two respective seasons. Similar trend was observed by Ulukan (2008) and Jamal \& Baghi (2014) and Ali et al. (2020).
Data presented in Table (7) reported that the tested grain sorghum genotypes had significant influence on grain yield. Applied fertilization treatments had a significant effect on grain yield ard/fed during the two seasons of study. The highest mean values of grain yield (18.56 and 18.72 ard /fed) in 2019 and 2020 seasons, respectively by the treatment application $\mathrm{N} 75 \%+\mathrm{H}+\mathrm{F}$. These findings are in a good line with those obtained by Ulukan (2008), Jamal and Baghi (2014), ALmaghir et al. (2019),Dulaimy \& El- Fahdawi (2020) and Ali et al.(2020). 
Scientific Journal of Agricultural Sciences 3 (2): 116-122, 2021

Table 6. Effect of humic $(\mathrm{H})$ and fulvic (F) acids as partial alternatives to mineral nitrogen (N) and their interaction of two genotypes of grain sorghum on 1000 - kernel weight.

\begin{tabular}{|c|c|c|c|c|c|c|}
\hline \multirow[b]{3}{*}{ Fertilization treatments } & \multirow{2}{*}{\multicolumn{2}{|c|}{$\begin{array}{l}2019 \\
\text { Genotypes }\end{array}$}} & \multirow[b]{3}{*}{ Mean } & \multirow{2}{*}{\multicolumn{2}{|c|}{\begin{tabular}{|l}
2020 \\
Genotypes
\end{tabular}}} & \multirow[b]{3}{*}{ Mean } \\
\hline & & & & & & \\
\hline & $\begin{array}{l}\text { Hybrid } \\
\text { Shandaweel-1 }\end{array}$ & $\begin{array}{l}\text { Hybrid } \\
306\end{array}$ & & $\begin{array}{l}\text { Hybrid } \\
\text { Shandaweel-1 }\end{array}$ & $\begin{array}{l}\text { Hybrid - } \\
306\end{array}$ & \\
\hline $\mathbf{N 1 0 0 \%}$ & 26.83 & 25.33 & 26.08 & 26.27 & 25.33 & 25.8 \\
\hline N $75 \%+H(25 \mathrm{ml} / \mathrm{L})$ & 24.67 & 26.33 & 25.5 & 25 & 25.57 & 25.28 \\
\hline $\mathrm{N} 75 \%+\mathrm{F}(25 \mathrm{ml} / \mathrm{L})$ & 26.5 & 26.07 & 26.28 & 27.23 & 26.6 & 26.92 \\
\hline $\mathrm{N} 75 \%+\mathrm{H}+\mathrm{F}(25 \mathrm{ml} / \mathrm{L})$ & 27.63 & 27.17 & 27.4 & 28.2 & 27.13 & 27.67 \\
\hline \multirow[t]{2}{*}{ Mean } & 26.41 & 26.23 & 26.32 & 26.68 & 26.16 & 26.42 \\
\hline & F test & LSD 0.05 & & F test & LSD 0.05 & \\
\hline Fertilization treatments & $* *$ & 0.96 & & $*$ & 1.48 & \\
\hline Genotypes & - & - & & - & - & \\
\hline Interaction & $*$ & 1.36 & & - & - & \\
\hline
\end{tabular}

Table 7. Effect of humic $(\mathrm{H})$ and fulvic $(\mathrm{F})$ acids as partial alternatives to mineral nitrogen $(\mathrm{N})$ and their interaction of two genotypes of grain sorghum on grain yield (ard /fed).

\begin{tabular}{|c|c|c|c|c|c|c|}
\hline Seasons & 2019 & & & 2020 & & \\
\hline \multirow[b]{2}{*}{ Fertilization treatments } & \multicolumn{2}{|l|}{ Genotypes } & \multirow[b]{2}{*}{ Mean } & \multicolumn{2}{|l|}{ Genotypes } & \multirow[b]{2}{*}{ Mean } \\
\hline & $\begin{array}{l}\text { Hybrid } \\
\text { Shandaweel-1 }\end{array}$ & $\begin{array}{l}\text { Hybrid } \\
-306\end{array}$ & & $\begin{array}{l}\text { Hybrid } \\
\text { Shandaweel-1 }\end{array}$ & $\begin{array}{l}\text { Hybrid } \\
-306\end{array}$ & \\
\hline N $100 \%$ & 17.04 & 16.29 & 16.66 & 17.27 & 16.64 & 16.96 \\
\hline N 75\% + H (25 ml/L) & 16.54 & 16.46 & 16.5 & 16.69 & 17.04 & 16.86 \\
\hline N 75\% +F $(25 \mathrm{ml} / \mathrm{L})$ & 18.09 & 17.57 & 17.83 & 18.4 & 17.78 & 18.09 \\
\hline N 75\% + H +F (25 ml/L) & 19.82 & 17.29 & 18.56 & 19.6 & 17.85 & 18.72 \\
\hline \multirow[t]{2}{*}{ Mean } & 17.87 & 16.9 & 17.39 & 17.99 & 17.33 & 17.66 \\
\hline & F test & \multicolumn{2}{|c|}{ LSD 0.05} & F test & \multicolumn{2}{|c|}{ LSD 0.05} \\
\hline Fertilization treatments & $*$ & \multicolumn{2}{|l|}{1.34} & $*$ & \multicolumn{2}{|l|}{1.19} \\
\hline Genotypes & $*$ & \multicolumn{2}{|l|}{0.95} & - & \multicolumn{2}{|l|}{-} \\
\hline Interaction & - & \multicolumn{2}{|l|}{-} & - & \multicolumn{2}{|l|}{-} \\
\hline
\end{tabular}

*and ** mean significant 5 and $1 \%$ at level of probability, respectively.

\section{CONCLUSIONS}

It could be concluded from the results of this study that, the humic and fulvic acids improved the soil properties and increase soil exchange capacity for ions and actions therefore its increase the plant ability to benefit the most of soil elements. All these improved properties reflected in enhanced yield and its components of grain sorghum. In addition, applic ation of humic and fulvic acids as partial substitute for mineral nitrogen led to reduced use of mineral nitrogen, costs production and environmental pollution. The genotype hybrid Shandaweel-1 surpassed in most studied characters compared to the genotype hybrid306. We recommended using humic and fulvic acids combined with $(\mathrm{N} 75 \%+\mathrm{H}+\mathrm{F})$. We could save $25 \%$ of the recommended dose and improved the soil properties.

\section{REFERENCES}

Ali EA, Abd El-Rahman KA, El-Far IA, Mohamed AH (2020). Response of some grain sorghum genotypes to foliar spray by humic acid. Assiut J. Agric. Sci., 51 (2) (54-63).

ALmaghir HAM, Al-Refai S, Saad T (2019). Effect of different levels of humic acid, fulvic acid and N P $\mathrm{K}$ in some growth properties and total seed yield of sunflower plant (Helianthus Annuus L.). Plant Archives Vol. 19 : 1336-1340.

Assefa A, Bezabih A, Girmay G, Alemayehu T, Lakew A (2020). Evaluation of sorghum (Sorghum 
bicolor (L.) Moench) variety performance in the lowlands area of wag lasta, north eastern Ethiopia. Cogent Food \& Agric., 6:1, 1778603.

Bulent AB, Turan A, Celik H, Katkat AV (2009). Effects of humic substances on plant growth and mineral nutrients uptake of wheat (Triticum durum cv. Salihli) under conditions of salinity. Asian J. of Crop Science. 1; 87-95.

Chapman HD, Pratt PF (1978). Methods of Analysis for Soils, Plant and Waters. University of Callifornia Division of Agriculture Science. Priced publication, 4034, 50 and 169.

Delfine S, Tognetti R, Desiderio E, Alvino A (2005). Effect of foliar application of $\mathrm{N}$ and humic acids on growth and yield of durum wheat. Agron. Sustainability 25: 183-191.

Dulaimy JAMA, El- Fahdawi WAT (2020). Effect of humic acid on growth and yield of barley humic acid as interacted with row spacing. Indian J. of Ecology (2020) 47 Special Issue (10): 62-65.

Economic Affairs Sector (2020). Bulletin of the agricultural statistics part 2 summer \& nili crops 2019/2020, ARE, ministry of agriculture and land reclamation 142-144.

Fagbenro JA, Agboola AA (1993). Effect of different levels of (humic acid on the growth and nutrient uptake of teak seedlings). J. Plant Nutr. 16(8): 1465.
Gomez KA, Gomez AA (1984). Statistic al Procedures for Agricultural Research. $2^{\text {nd }}$ Edn., John Wily and Sons, New York, pp: 68.

Hassan AB, Shalaby EMM, Allam AY, Ali EA, Said MT (2014). Effect of NPK fertilization rates and splitting on the grain yield and its components of Two Sorghum Cultivars. Assiut J. Agric. Sci., (45) No. (4) (1-14).

Jamal S, Baghi M (2014). Evaluation of the effect of various amounts of humic acid on yield, yield components and protein of chickpea cultivars (Cicer Arietinum L.) Int. J. Adv. Biol. Biom. Res, 2 (7), 2306-2313.

Kauser A, Azam F (2006). Effect of humic acid on wheat seeding growth. Envir. and Experimental Botany 25: 245-252.

Sabzevari S, Khazaei H, Kafi M (2010). The effect of humic acid on germination of four cultivars of fall wheat (Saions and Sabaln) and spring wheat. J. Agric. Res. 8(3): 473-480.

SAS institute (2008). The SAS System for Window s, release 9.2. Cary NC: SAS institute.

Shalash GS, Ismail AA, KG A (2011). Response of olive seedlings to foliar application with hemomogrin and iron-zinc mixture. J. Agric. Sci. 43(1): 58-75.

Ulukan H (2008). Effect of soil applied humic acid at different sowing times on yield in wheat. Int. J. of Botany 4:164-175. 


\title{
الملخص العربي
}

\section{تأثير الرش الورقى بأحماض الهريويك والفولفيك كإحلال جزئي للنيترجين المعدني علي بعض صفات هجينين من الأرة الرفيعة للحبوب}

\author{
أمل عبد الرحيم تاج الدين، هبة محمد حافظ، عمر أبو الحسن يونس عبد الرحيم \\ قسم بحوث الذرة الرفيعة - معهد بحوث المحاصيل الحقلية - مركز البحوث الزراعية
}

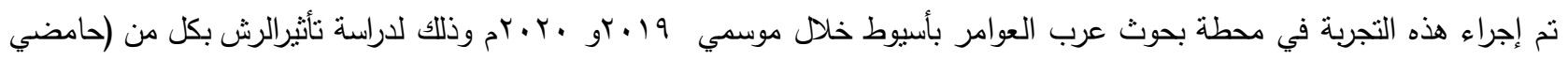

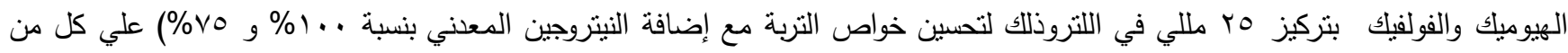

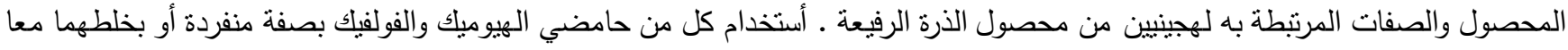
بنسبة ا:ا مع النيتروجين المعدني هV\% ـ أوضحت النتائج اختلافات معنوية أوعالية المعنوية لكل من الهجينين خلال الموسمين وذلك بالنسبة لصفتي طول النبات وطول القنديل . كذلك أوضحت النتائج تأثنرا معنويا لإنتاجية المحصول أردب /فدان خلال الموسم الأول. أعطى الهجين

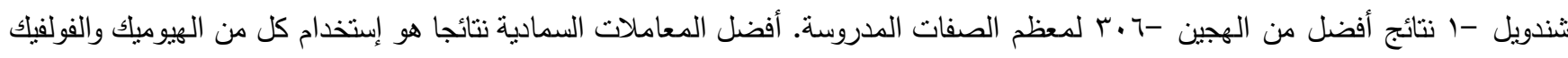

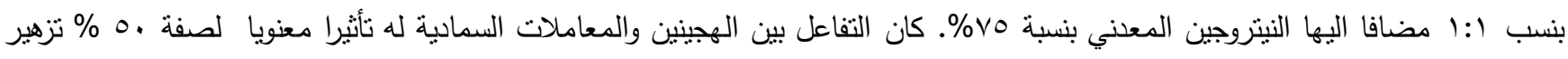

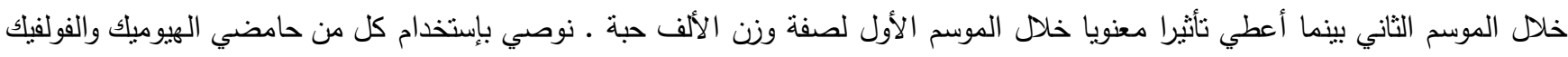

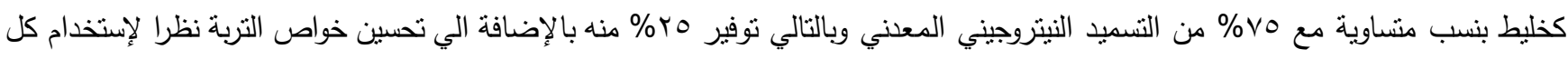
من حامضي الهيوميك والفولفيك. 